\title{
FAKTOR PERSONAL HYGIENE DENGAN KEBERADAAN ESCHERICHIA COLI PADA MAKANAN DI JASABOGA ASRAMA HAJI SURABAYA
}

\author{
Khuliyah Candraning Diyanah ${ }^{1}$, Nunki Nirmalasari ${ }^{2}$, Roro Azizah ${ }^{3}$, Aditya Sukma \\ Pawitra $^{4}$ \\ Departemen Kesehatan Lingkungan, Fakultas Kesehatan Masyarakat Universitas Airlangga, \\ Surabaya Indonesia ${ }^{1,3,4}$, Kantor Kesehatan Pelabuhan Kelas 1 Surabaya Indonesia ${ }^{2}$ \\ k.c.diyanah@fkm.unair.ac.id ${ }^{1}$, nunkinirmalasari@gmail.com ${ }^{2}$
}

\begin{abstract}
Hygiene and sanitation are important in determining food quality, where Escherichia coli is an indicator of food pollution that can cause foodborne illness. The purpose of this study is to analyze the personal hygiene factors of food handlers by contamination of Escherichia coli in the food provided in Surabaya haj boarding services. The method used was observational with a crosssectional approach. The research population were 57 food handlers and 57 food samples in Surabaya hajj boarding services. This study used total population. The variables in this study include the characteristics of the respondents (gender, age, education level) and personal hygiene, and the dependent variable is the presence of Escherichia coli in food. The statistical test used is the chisquare test. There was a personal hygiene relationship between food handlers and the presence of Escherichia coli in food at Jasaboga Hajj Dormitory Surabaya $(p=0.001 ; p<0.005)$. The level of closeness of the two relationships is strong $(C=0.454 ; C=0.41-0.70)$. The presence of Escherichia coli in food indicates contamination of human waste and improper food handlers behavior so corrective action is needed.
\end{abstract}

Keywords: Catering; Escherichia coli; Foodborne Illness; Personal Hygiene

\begin{abstract}
ABSTRAK
Higiene dan sanitasi merupakan hal yang penting dalam menentukan kualitas makanan dimana Escherichia coli sebagai salah satu indikator terjadinya pencemaran makanan yang dapat menyebabkan penyakit akibat makanan. Tujuan dari penelitian ini adalah untuk menganalisis faktor personal hygiene penjamah makanan dengan kontaminasi Escherichia coli pada makanan yang disediakan di jasaboga asrama haji Surabaya. Metode yang digunakan adalah observasional dengan pendekatan cross-sectional. Populasi penelitian adalah 57 penjamah makanan dan 57 sampel makanan di jasaboga asrama haji Surabaya. Penelitian ini menggunakan total populasi. Variabel dalam penelitian ini meliputi karakteristik responden (jenis kelamin, usia, tingkat Pendidikan) dan personal hygiene, serta variabel terikat yaitu keberadaan Escherichia coli pada makanan. Uji statistik yang digunakan adalah uji chi-square. Ada hubungan personal hygiene penjamah makanan dengan keberadaan Escherichia coli pada makanan di Jasaboga Asrama Haji Surabaya ( $\mathrm{p}=0,001 ; \mathrm{p}<0,005)$. Tingkat keeratan hubungan keduanya kuat $(\mathrm{C}=0,454 ; \mathrm{C}=0,41-0,70)$. Keberadaan Escherichia coli pada makanan menandakan adanya kontaminasi kotoran manusia dan adanya perilaku penjamah makanan yang tidak tepat sehingga perlu tindakan korektif.
\end{abstract}

Kata kunci: Jasaboga; Escherichia coli; Foodborne illness; Personal Hygiene

\section{PENDAHULUAN}

Makanan menurut World Health

Organization (WHO) adalah semua substansi yang diperlukan tubuh kecuali air dan obat-obatan dan substansi yang dipergunakan untuk pengobatan. Namun apabila makanan yang dimakan tidak aman dan sudah tidak sehat maka akan berbahaya dan tidak memberikan manfaat bagi tubuh (Wulandari dan Wahyudin, 2018). Manajemen makanan yang baik dan benar, peralatan yang berkualitas, dan penjamah makanan yang sehat dan didukung oleh fasilitas sanitasi yang memadai, kualitas 
dari makanan yang diproduksi dapat memenuhi kebutuhan makanan sehat dan aman bagi masyarakat, terutama makanan siap saji (Kemenkes RI, 2011). Pengelolaan makanan oleh jasaboga harus memenuhi higiene sanitasi dan dilakukan sesuai cara pengolahan makanan yang baik. Pemeriksaan dan penilaian jasaboga atau katering bagi calon jamaah haji sangat diperlukan dalam mempersiapkan penyelenggaraan operasional haji pada akhirnya akan dapat mewujudkan kondisi kesehatan calon jamaah haji Indonesia secara optimal untuk dapat menunaikan ibadah haji dengan aman, nyaman dan lancar (Kemenkes RI, 2016).

Salah satu mikroorganisme patogen yang sering ditemukan pada anak-anak yang mengalami diare akut di pusat pelayanan kesehatan di negara-negara berkembang adalah enterotoksigenik Escherichia coli dengan prevalensi 1020\%, sedangkan Escherichia coli enteropatogenik dengan prevalensi 1-5\%. Penyakit ini pada dasarnya terkait dengan perawatan suhu dan waktu makanan selama persiapan dan penyimpanannya (WHO, 2006). Penelitian yang dilakukan pada 43 jasaboga di wilayah Jakarta menunjukkan ditemukannya kuman Escherichia coli dan Staphylococcus aureus pada sampel makanan, yang menunjukkan perlu pengecekan kebersihan dan sanitasi pada usaha jasaboga (Pracoyo, dkk. 2008).

Di Inggris dan Wales, penyakit yang ditularkan melalui makanan menghasilkan sekitar 1,3 juta kasus, 21.000 dirawat di rumah sakit dan 500 kematian setiap tahun (Adak, 2002). Sementara itu, di Australia, sekitar 5,4 juta kasus, 15.000 dirawat di rumah sakit dan 120 kematian dilaporkan setiap tahun (Kirk, dkk. 2008). Data yang diperoleh di BPOM selama 2016 mengenai kejadian kasus keracunan makanan tercatat 1.661 kasus (makanan 758 kasus, minuman 903 kasus) yang berasal dari 33 provinsi di Indonesia (BPOM RI, 2016). Selama tahun 2017 sebanyak 53 kejadian luar biasa (KLB) keracunan pangan yang berasal dari
34 provinsi di Indonesia. Dilaporkan sebanyak 20141 orang sakit dan 3 orang meninggal dunia. Jenis makanan penyebab KLB keracunan pangan tahun 2017 adalah masakan rumah tangga sebanyak 20 kejadian (37,74\%), makanan jajanan / siap saji sebanyak 6 kejadian $(11,32 \%)$ dan makanan jasa boga sebanyak 7 kejadian 13,21\% (BPOM RI, 2017).

Ada beberapa faktor yang mempengaruhi terjadinya keracunan makanan, antara lain adalah hygiene perorangan yang buruk, cara penanganan makanan yang tidak sehat dan perlengkapan pengolahan makanan yang tidak bersih. Salah satu penyebabnya adalah karena kurangnya pengetahuan dalam memperhatikan kesehatan diri dan lingkungannya dalam proses pengolahan makanan yang baik dan sehat (Zulaekah, 2012); (Musfiroh dan Wisudaningtyas, 2014). Dari penelitian Kurniadi, dkk. 2013 menyebutkan tenaga penjamah yang tidak memenuhi syarat mempunyai peluang terkontaminasi Escherichia coli sebanyak 4,5 kali dibandingkan dengan tenaga penjamah yang memenuhi syarat.

Sebelum Calon Jamaah Haji (CJH) melakukan perjalanan ibadah haji ke Negara Saudi Arabia, mereka harus dikarantina terlebih dahulu selama $1 \times 24$ jam di Asrama Haji Surabaya. Selama CJH tinggal di Asrama Haji, semua makanan dan minuman disediakan oleh katering Asrama Haji. Para CJH tidak diperbolehkan membawa ataupun membeli makanan dan minuman dari luar selama di Asrama Haji. Hal ini bertujuan untuk memastikan bahwa makanan dan minuman yang dikonsumsi oleh CJH aman dan sehat sesuai dengan persyaratan Kementerian Kesehatan. Keamanan makanan dan minuman yang dikonsumsi CJH menjadi prioritas utama bagi Kementerian Agama bekerjasama dengan Kementerian Kesehatan. Dengan keamanan makanan yang terjamin mutunya tentunya dapat meningkatkan derajad kesehatan bagi $\mathrm{CJH}$, sehingga $\mathrm{CJH}$ dapat melaksanakan ibadah haji dengan lancar 
tanpa adanya gangguan kesehatan.

Berdasarkan latar belakang di atas, penelitian ini bertujuan untuk menganalisis hubungan antara personal hygiene dan sanitasi makanan, yang meliputi praktik mencuci tangan dengan sabun sebelum dan sesudah mengolah makanan, penggunaan alat bantu saat mengolah makanan, pemakaian Alat Pelindung Diri (celemek, tutup kepala, masker, sarung tangan), Kebersihan diri penjamah dengan keberadaan Escherichia coli pada makanan yang disediakan di katering Asrama Haji Surabaya.

\section{METODE}

Metode yang digunakan dalam penelitian ini adalah observasional dengan pendekatan cross sectional. Populasi penelitian adalah 57 (lima puluh tujuh) penjamah makanan dan 57 (lima puluh tujuh) sampel makanan di jasaboga asrama haji Surabaya. Penelitian ini menggunakan total populasi. Variabel dalam penelitian ini meliputi karakteristik responden (jenis kelamin, usia, tingkat Pendidikan) dan personal hygiene, serta variable terikat yaitu keberadaan Escherichia coli pada makanan. Uji statistik yang digunakan adalah uji chi-square. Analisis data dilakukan menggunakan teknik analisis univariat dan bivariat. Pengumpulan data dilakukan dengan observasi dan wawancara dengan menggunakan check list dan pemeriksaan laboratorium untuk indikator Escherichia coli. Pengambilan sampel makanan dilakukan secara aseptic menggunakan instrumen steril. Angka kuman Escherichia coli pada makanan harus 0/gram sampel makanan (Kemenkes RI, 2011).

\section{HASIL}

Data penelitian ini diperoleh hasil karakteristik dasar subjek penelitian berdasarkan umur, jenis kelamin, dan pendidikan sebagai berikut: Usia responden paling banyak berusia 21-30 tahun yaitu sebanyak 36,9 \%. Mayoritas responden berumur berjenis kelamin laki-laki yaitu sebanyak 52,6 \%. Sebagian besar responden berpendidikan rendah (< Sekolah Menengah Atas (SMA)) yaitu sebanyak 59,7 \%. Seluruh penjamah yaitu sebanyak 57 orang telah mengikuti kursus atau pelatihan higiene dan sanitasi makanan dengan materi yang telah ditetapkan oleh Kementerian Kesehatan. Data karakteristik responden dapat dilihat pada Tabel 1.

Tabel 1. Karakteristik Responden di Jasaboga Asrama Haji Surabaya

\begin{tabular}{lll}
\hline Karakteristik Responden & \multicolumn{2}{c}{ Frekuensi } \\
& n & \% \\
\hline Jenis Kelamin & 30 & 52,6 \\
$\quad$ Laki-laki & 27 & 47,4 \\
$\quad$ Perempuan & & \\
Usia (tahun) & 21 & 36,9 \\
$\quad 21-30$ & 17 & 29,8 \\
$31-40$ & 19 & 33,3 \\
$\quad 41-50$ & & \\
Tingkat Pendidikan & 23 & 40,3 \\
$\quad$ Tinggi ( $\geq$ SMA) & 34 & 59,7 \\
$\quad$ Rendah (< SMA) & & \\
Telah Mengikuti Kursus & & \\
$\begin{array}{l}\text { Penjamah Makanan } \\
\text { Ya }\end{array}$ & 57 & 100,0 \\
\hline
\end{tabular}

Sebagian besar penjamah makanan di Jasaboga Asrama Haji Surabaya mempunyai personal hygiene baik sebanyak $84,2 \%$, dan $15,8 \%$ mempunyai personal hygiene tidak baik. Berikut ini merupakan distribusi responden berdasarkan praktik higiene yang dilakukan para penjamah makanan di Asrama Haji Surabaya yang dikategorikan menjadi 2 yaitu baik dan kurang baik yang disajikan dalam Tabel 2.

Tabel 2. Distribusi Frekuensi Praktik Higiene Responden di Jasaboga Asrama Haji Surabaya

\begin{tabular}{lrr}
\hline \multicolumn{1}{c}{$\begin{array}{c}\text { Praktik } \\
\text { Higiene }\end{array}$} & Frekuensi (n) & \multicolumn{1}{c}{$\begin{array}{c}\text { Persentase } \\
(\boldsymbol{\%})\end{array}$} \\
\hline Baik & 48 & 84,2 \\
Kurang baik & 9 & 15,8 \\
\hline
\end{tabular}

Dari observasi praktik penjamah makanan, didapatkan hasil bahwa ada 
beberapa personal hygiene yang sebagian besar tidak dilakukan penjamah di Jasaboga Asrama Haji Surabaya antara lain 77,2\% penjamah makanan tidak menggunakan sarung tangan atau penjepit atau alat pengaman dalam mengambil makanan lainnya, mereka langsung menggunakan tangan tanpa alas. $61,4 \%$ penjamah tidak mencuci tangan sebelum bekerja, setelah bekerja dan setelah keluar dari toilet/jamban. 52,6\% penjamah makanan tidak memakai tutup kepala pada saat bekerja. Personal hygiene yang sebagian besar telah dipraktikkan oleh penjamah dengan baik yaitu tidak berbicara saat bekerja, menggunakan celemek saat bekerja, tidak memakai perhiasan, kecuali cincin kawin yang tidak berhias (polos), menggunakan masker saat bekerja, kuku terpelihara pendek, dan tidak makan atau mengunyah saat bekerja. Distribusi Perilaku personal higiene responden dalam pengolahan makanan dapat dilihat pada Tabel 3.

Tabel 3. Distribusi Perilaku Personal Hygiene Responden di Jasaboga Asrama Haji Surabaya

\begin{tabular}{lcc}
\multicolumn{1}{c}{ Variabel } & \multicolumn{2}{c}{ Frekuensi } \\
& n & \% \\
\hline $\begin{array}{l}\text { Tidak menggunakan alat saat kontak } \\
\text { dengan } \\
\text { makanan }\end{array}$ & 44 & 77,2 \\
$\begin{array}{l}\text { Tidak Mencuci tangan sebelum } \\
\text { /setelah } \\
\text { bekerja dan setelah keluar dari toilet } \\
\begin{array}{l}\text { Tidak memakai tutup kepala saat } \\
\text { bekerja }\end{array}\end{array}$ & 35 & 61,4 \\
\hline
\end{tabular}

\begin{tabular}{lcr}
\hline \multicolumn{1}{c}{ Variabel } & \multicolumn{2}{c}{ Frekuensi } \\
& n & \% \\
\hline Tidak berbicara saat bekerja & 42 & 73,7 \\
Tidak memakai perhiasan kecuali & 52 & 91,2 \\
cincin & & \\
kawin & & \\
Menggunakana masker saat bekerja & 49 & 86,0 \\
Menggunakan apron saat bekerja & 50 & 87,7 \\
$\begin{array}{l}\text { Kuku terpelihara dan pendek } \\
\text { Tidak mengunyah makanan saat }\end{array}$ & 51 & 89,5 \\
bekerja & 55 & 96,5 \\
\hline
\end{tabular}

Dari 57 sampel makanan yang diperiksa dari jasaboga Asrama Haji Surabaya, sebanyak $29,8 \%$ positif Escherichia coli.

Tabel 4. Distribusi Keberadaan Escherichia coli pada makanan di Jasaboga Asrama Haji Surabaya

\begin{tabular}{lcc}
\hline $\begin{array}{c}\text { Keberadaan } \boldsymbol{E} \text {. Coli pada } \\
\text { makanan }\end{array}$ & \multicolumn{2}{c}{ Frekuensi } \\
& n & \% \\
\hline Ada & 17 & 29,8 \\
Tidak ada & 40 & 70,2 \\
\hline
\end{tabular}

Hasil analisis bivariat untuk mengetahui hubungan antara personal hygiene penjamah makanan dengan keberadaan Escherichia coli pada makanan di Jasaboga Asrama Haji Surabaya disajikan dalam Tabel 5. Hasil penelitian ini menunjukkan bahwa ada hubungan personal hygiene penjamah makanan dengan keberadaan Escherichia coli pada makanan di Jasaboga Asrama Haji Surabaya $(p=0,001 ; p<0,005)$. Tingkat keeratan hubungan keduanya kuat $(\mathrm{C}=0,454 ; \mathrm{C}=0,41-0,70)$.

Tabel 5. Tabulasi Silang Personal Hygiene Penjamah Makanan dengan Keberadaan Escherichia Coli pada Makanan di Jasaboga Asrama Haji Surabaya

\begin{tabular}{|c|c|c|c|c|c|c|c|c|c|}
\hline \multirow{3}{*}{$\begin{array}{l}\text { Personal } \\
\text { hygiene }\end{array}$} & \multicolumn{6}{|c|}{ Keberadaan Escherichia coli } & \multirow{3}{*}{$\mathbf{X}^{2}$} & \multirow{3}{*}{$\mathbf{P}$} & \multirow{3}{*}{$\mathbf{C}$} \\
\hline & \multicolumn{2}{|c|}{ Ada } & \multicolumn{2}{|c|}{ Tidak ada } & \multicolumn{2}{|c|}{ Total } & & & \\
\hline & Frekuensi & $\%$ & Frekuensi & $\%$ & Frekuensi & $\%$ & & & \\
\hline Tidak baik & 7 & 33,3 & 2 & 66,7 & 9 & 100 & 11,742 & 0,001 & 0,454 \\
\hline Baik & 10 & 29,2 & 38 & 70,8 & 48 & 100 & & & \\
\hline
\end{tabular}




\section{PEMBAHASAN}

Berdasarkan hasil penelitian, sebagian besar proporsi jenis kelamin penjamah makanan di jasaboga asrama haji Surabaya yaitu laki-laki $(52,6 \%)$ dan usia $21-30$ tahun sebesar 36,9\%. Laki-laki mempunyai motivasi lebih rendah dalam menjaga kebersihan dan kesehatan pribadi serta lingkungan dibandingkan perempuan, karena pada umumnya perempuan lebih sensitif dan mau menerima masukan baik terutama untuk masalah kesehatan (Syachroni, 2012). Usia pekerja dewasa awal diyakini dapat membangun kesehatannya melalui upaya pencegahan penyakit dengan menjaga kebersihan perorangan (Erfandi, 2009).

Sebagian besar responden dalam penelitian ini berpendidikan rendah $(<$ SMA) yaitu sebanyak 59,7\%. Penelitian Agustin dan Adriyani (2008) tentang hygiene dan sanitasi nasi tempe penyet, mendapatkan ada hubungan antara kebersihan dengan pendidikan, terutama setelah mencapai tingkat SMP. Tingkat pendidikan yang cukup tinggi diharapkan dapat meningkatkan kesadaran dan memanfaatkan pengetahuan terhadap praktik personal hygiene.

Bakteri Escherichia coli umumnya mampu bertahan hidup pada suhu antara 8 ${ }^{\circ} \mathrm{C}-46{ }^{\circ} \mathrm{C}$. Bakteri Eschericia coli berada di dapur, tempat persiapan bahan baku, serta pengolahan, selanjutnya masuk ke makanan yang telah dimasak melalui tangan, permukaan alat, tempat masakan, dan peralatan lainnya. Dari 57 sampel makanan yang diperiksa dari jasaboga Asrama Haji Surabaya, sebanyak 17 sampel makanan positif bakteri Escherichia coli. Jumlah Eschericia coli yang tinggi umumnya menyiratkan kurangnya Good Manufacturing Practices (GMP), serta sanitasi permukaan yang buruk atau tidak tepat (Sangadkit, dkk. 2012).

Hasil dari penelitian ini menunjukkan adanya hubungan antara personal hygiene penjamah makanan dengan keberadaan Escherichia coli pada makanan di Jasaboga Asrama Haji Surabaya ( $\mathrm{p}=$ $0,001 ; \mathrm{p}<0,005)$. Hal ini sejalan dengan penelitian Romanda, dkk. (2016) yang menunjukkan ada hubungan personal hygiene dengan keberadaan Escherichia coli pada makanan di Tempat Pengolahan Makanan Buffer Area Bandara Adi Soemarmo Surakarta.

Perilaku personal hygiene penjamah makanan di jasaboga asrama haji Surabaya yang tidak sesuai diantaranya yaitu tidak menggunakan alat saat kontak dengan makanan, tidak mencuci tangan sebelum /setelah bekerja dan setelah keluar dari toilet dan tidak memakai tutup kepala saat bekerja. Sebanyak 77,2\% penjamah makanan tidak menggunakan sarung tangan atau penjepit dalam mengambil makanan. Alasannya adalah dikarenakan akan memperlambat dalam penyajian dan ketidaknyamanan menggunakan alat bantu pada saat mengolah makanan. Sentuhan tangan merupakan penyebab yang paling umum terjadinya pencemaran makanan. Mikroorganisme yang melekat pada tangan akan berpindah ke dalam makanan dan akan berkembang biak dalam makanan. (Agustina, 2009). Menurut penelitian yang dilakukan Lambrechts, dkk. 2014, tangan penjamah makanan sebagai vektor penyebaran penyakit bawaan makanan sehingga perlu personal hygiene yang baik agar dapat menghasilkan mutu pangan yang baik pula. Tangan harus selalu dijaga kebersihannya dengan memotong kuku, kulit selalu bersih, dan bebas dari luka. Semua kegiatan pengolahan makanan harus dilakukan dengan cara terlindung dari kontak langsung dengan tubuh. Perlindungan kontak langsung dengan makanan dilakukan dengan menggunakan 
sarung tangan plastik sekali pakai (disposal), penjepit makanan dan sendok garpu (Kemenkes RI, 2011).

Penjamah yang tidak mencuci tangan dengan sabun sebelum bekerja, setelah bekerja dan setelah keluar dari toilet/jamban sebanyak 61,4\%. Pada saat mencuci tangan, penjamah makanan tidak membersihkan sela-sela jari yang kemungkinan terdapat bakteri yang dapast menimbulkan kontaminasi. Kegiatan mencuci tangan dengan sabun sebelum menjamah makanan menjadi salah satu cara untuk mencegah kontaminasi bakteri Escherichia coli yang kemudian dapat menimbulkan infeksi bila masuk ke dalam tubuh (CDC, 2005). Berdasarkan penelitian Puspita, dkk. 2013, kebiasaan mencuci tangan sebelum menjamah makanan dapat memperkecil risiko terjadinya kontaminasi bakteri dari tangan ke makanan. Penggunaan air dan sabun dalam mencuci tangan bisa menurunkan sebanyak 8\% keberadaan bakteri (Burton, dkk. 2011). Sabun cuci tangan yang banyak beredar mengandung bahan aktif triklosan yang dapat berfungsi sebagai antimikroba (Wijaya, 2013). Kebiasaan tidak mencuci tangan sebelum dan sesudah mengolah makanan atau setelah keluar dari toilet/jamban merupakan sumber kontaminan yang cukup berpengaruh terhadap kebersihan bahan makanan yang diolah.

Penjamah makanan merupakan sumber utama kontaminasi makanan. Untuk melindungi pencemaran terhadap makanan, penjamah makanan dapat menggunakan celemek, tutup rambut dan maskerr (Depkes RI, 2010). Dari hasil penelitian diketahui perilaku personal higiene penjamah makanan yang tidak baik adalah tidak memakai penutup rambut saat bekerja sebanyak 52,6\%. Selama pengolahan dan peyajian makanan harus dijaga agar rambut tidak terjatuh kedalam makanan. Bisa terjadi kontaminasi silang apabila rambut dibiarkan tanpa tutup kepala dalam proses memasak. Penjamah makanan yang tidak menggunakan tutup rambut adalah laki-laki. Untuk penjamah perempuan telah menutup rambutnya dengan menggunakan kerudung.

Makanan atau peralatan yang kontak langsung dengan air maupun lingkungan yang tercemar apabila didapatkan hasil laboratorium adanya bakteri Escherichia coli mengindikasikan bahwa makanan tersebut pernah terkontaminasi kotoran manusia (Falamy, dkk. 2013). Penyakit yang disebarkan melalui makanan bisa dikaitkan dengan praktik penjamah makanan yang tidak tepat pada saat menyajikan makanan (Sylvia, dkk. 2015). Adapun penjamah yang mempunyai personal hygiene baik tetapi makanan mengandung Escherichia coli pada dasarnya berhubungan dengan perlsakuan suhu dan proses penyimpanan yang tidak tepat (WHO, 2006). Kontaminasi Escherichia coli dapat meningkat 2 kali lipat jika makanan disimpan pada ruang terbuka (Burton, dkk. 2010). Dalam menunjang praktik yang baik sehingga membentuk perilaku higiene personal yang benar, fasilitas yang disediakan juga sangat mendukung. Fasilitas yang berhubungan dengan higiene penjamah, seperti penyediaan air, tempat mencuci tangan dan sabun, kelengkapan pakaian kerja (seragam, celemek, penutup rambut, masker, dan sarung tangan).

\section{KESIMPULAN}

Keberadaan Escherichia coli pada makanan menandakan adanya kontaminasi kotoran manusia dan adanya perilaku penjamah makanan yang tidak tepat sehingga perlu tindakan korektif. Pengetahuan yang memadai tentang prinsip kebersihan makanan oleh penjamah makanan di katering sangat diperlukan sebagai upaya pengendalian makanan terkontaminasi bakteri Escherichia coli. Selama persiapan dan penyimpanan peralatan makan dan minum, kebersihan dapur, sikap penjamah 
makanan dalam mengolah makanan dan mencuci peralatan makan/minum adalah faktor risiko utama menurunnya kualitas mikrobiologis

\section{UCAPAN TERIMA KASIH}

Penulis ingin menyampaikan penghargaan yang tulus kepada setiap bagian yang terlibat dalam penelitian ini. KKP Kelas 1 Surabaya, dan pihak lain yang tidak dapat kami sebutkan satu per satu.

\section{DAFTAR PUSTAKA}

Adak GL. (2002). Trends in indigenous foodborne disease and deaths, England and Wales: 1992 to 2000. Gut. 2002;51(6):832-41

Agustin, TE. dan Adriyani, R. (2008). Hygiene and Sanitation of Nasi Tempe Penyet at Karangmenjangan Street Vendors, Surabaya. Media Kesehatan Lingkungan. 2008;4(2)

Agustina, F. (2009). Higiene dan Sanitasi pada Pedagang Makanan Jajanan Tradisional di Lingkungan Sekolah Dasar di Kelurahan Demang Lebar Daun Palembang Tahun 2009. Jurnal Publikasi Ilmiah Fakultas Kesehatan Masyarakat Universitas Sriwijaya https://repository.unsri.ac.id/23397/

Bhausaheb A, Associate M, Kesharwani N, Mudey GA, Goyal RC, Dawale AK, et al. Health Status and Personal Hygiene among Food Handlers Working at Food Establishment around a Rural Teaching Hospital in Wardha District of Maharashtra, India. Glob J Health Sci [Internet]. 2010;2(2):198-206. Available from: www.ccsenet.org/gjhs

BPOM RI. 2016. Badan Pengawas Obat dan Makanan, Laporan Tahunan 2016 [Internet]. 2016. Available from: http://www.pom.go.id/new/admin/d at/20171127/laptah2016.pdf

BPOM RI. (2017). Badan Pengawas Obat dan Makanan, Laporan Tahunan 2017.

Burton M, Cobb E, Donachie P, Judah G, Curtis V, Schmidt WP. (2011). The effect of handwashing with water or soap on bacterial contamination of hands. Int $\mathrm{J}$ Environ Res Public Health. 2011;8(1):97-104

Cahyaningsih, CT., Kushadiwijaya, H., dan Tholib, A. (2009). Hubungan Higiene Sanitasi dan Perilaku Penjamah Makanan dengan Kualitas Bakteriologis Peralatan Makan di Warung Makan. Beritas Kedokteran Masyarakat. 2009;25(4):180-8

CDC. (2005). Bacterial Foodborne and Diarrheal Disease National Case Surveillance: annual report, 2005. Enteric Diseases Epidemiology Branch Division of Foodborne, Bacterial, and Mycotic Diseases National Center for Zoonotic, Vector-Borne, and Enteric Diseases Centers for Disease Control and Prevention

Depkes RI. (2010). Kumpulan Modul Kursus Hygiene Sanitasi Makanan dan Minuman. 2006. Jakarta: Sub Direktorat Sanitasi Makanan \& Bahan Pangan Direktorat Penyehatan Lingkungan Direktorat PP \& PL Kementrian Kesehatan RI

Erfandi. (2009). Pengetahuan dan FaktorFaktor yang Mempengaruhi Pengetahuan. Diakses dari http://academia.edu.id

Falamy, R., Warganegara E, Apriliana E. (2013). Deteksi Bakteri Coliform pada Jajanan Pasar Cincau Hitam di Pasar Tradisional dan Swalayan Kota Bandar Lampung. Medical Journal of Lampung University 2013;2(5);ISSN 2337-:1-9.

Kemenkes RI. (2011). Peraturan Menteri Kesehatan Republik Indonesia No. 1096/MENKES/PER/VI/2011 
tentang Higiene Sanitasi Jasaboga. Jakarta : Kementerian Kesehatan RI

Kemenkes RI. (2016). Peraturan Menteri Kesehatan Republik Indonesia No. 62 tahun 2016 tentang Penyelenggaraan Kesehatan Haji. Jakarta : Kementerian Kesehatan RI Kirk MD, McKay I, Hall GV, Dalton CB, Stafford R, Unicomb L. (2008). Food Safety: Foodborne Disease in Australia: The OzFoodNet Experience. Clin Infect Dis. 2008;47(3):392-400

Kurniadi Y, Saam Z, Afandi D. (2013). Faktor Kontaminasi Bakteri E. Coli pada Makanan Jajanan di Lingkungan Kantin Sekolah Dasar Wilayah Kecamatan Bangkingan. Jurnal Ilmu Lingkungan. 2013;7(1):28-37

Lambrechts AA, Human IS, Doughari JH, Lues JFR. (2014). Bacterial Contamination of The Hands of Food Handlers as Indicator of hand washing efficacy in some convenient food industries. Pakistan J Med Sci. 2014;30(4):755-8

Musfiroh, M. dan Wisudaningtyas, BL. (2014). Penyuluhan terhadap Sikap Ibu dalam Memberikan Toilet Training pada Anak. KESMAS Jurnal Kesehatan Masyarakat. 2014;9(2):157-66

Pracoyo, NE., Harjining, $\quad S$., dan Pudjarwoto, T. (2008). Infeksi Nosokomial III. Cermin Dunia Kedokteran 2008;83:1-4

Puspita I, Palandeng H, Sinolungan J. (2013). Hubungan Praktik Higiene Sanitasi Penjamah Makanan terhadap Cemaran Escherichia Coli Pada Makanan Gado-Gado Di Sepanjang Jalan Kota Manado. Fakultas Kesehatan Masyarakat Universitas Sam Ratulangi

Romanda, F., Priyambodo, dan Risanti, ED. (2016). Hubungan Personal Hygiene dengan Keberadaan Escherichia coli pada Makanan di
Tempat Pengolahan Makanan (TPM) Buffer Area Bandara Adi Soemarmo Surakarta. Biomedika 2016;8(1): 41 - 46

Syahroni, M. (2010). Perbedaan Motivasi Perempuan dan Laki-laki Dalam Hal Kesehatan

Sangadkit W, Rattanabumrung O, Supanivatin P, Thipayarat A. (2012). Practical Coliforms and Escherichia coli Detection and Enumeration for Industrial Food Samples Using Low-cost Digital Microscopy. Procedia Eng [Internet]. 2012;32:126-33. Available from: http://dx.doi.org/10.1016/j.proeng.2 $\underline{012.01 .1246}$

Sylvia AB, RoseAnn M, John BK. (2015). Hygiene Practices and Food Contamination in Managed Food Service Facilities in Uganda. African J Food Sci. 2015;9(1):3142

WHO. (2006). Working Together for Health, The World Health Report 2006 [Internet]. Vol. 19, World Health Organozation. Available from:

http://apps.who.int/iris/bitstream/10 665/43432/1/9241563176_eng.pdf

Wijaya JI. (2013). Formulasi Sediaan Gel Hand Sanitizer dengan Bahan Aktif Triclosan 1,5\% dan 2\%. Calyptra: Jurnal Ilmiah Mahasiswa Universitas Surabaya. 2013;2(1):114

Wulandari, K. dan Wahyudin, D. (2018). Bahan Ajar Kesehatan Lingkungan: Saniatsi Rumah Sakit. Pusat Pendidikan Sumber Daya Manusia Kesehatan

Zulaekah, S. (2012). Pendidikan Gizi Dengan Media Booklet terhadap Pengetahuan Gizi. KEMAS. Jurnal Kesehatan Masyarakat 2012;7 (2): 102-107 